\title{
POSSIBILITIES FOR CALCIUM AND BICARBONATE-RICH MINERAL WATERS USE IN THE PREVENTION OF CALCIUM-DEFICIT CONDITIONS
}

\author{
Ivan S. Lemko, Serhij T. Shubert, Margarita O. Haysak, \\ Viktorija G. Malinovska, Lyudmila V. Dychka
}

\section{Government Institution "The Scientific-practical Medical Centre "Rehabilitation" Health Ministry of Ukraine”, Uzhgorod, Ukraine}

Summary. Investigation of bioavailability of calcium, magnesium and iron by the dynamics of their content in the hair testified high level of absorption of these elements from the natural mineral water as a result of its intake. Peculiarities of natural calcium containing mineral waters intake influence on the calcium-magnesium metabolism at patients with digestive organs pathology and osteoporosis risk factors was studied. This effect quantitatively depended on the concentration of calcium and magnesium in the serum at the beginning of treatment and on their content in the mineral water. The revealed regularities serve as the basis for the differential use of natural mineral waters with biologically significant levels of calcium in the programs of primary prophylaxis of osteoporosis and treatment of calcium-deficit conditions.

Keywords: calcium-deficit, bicarbonate-rich and calcium-rich mineral waters, preventive treatment, bioavailability.

\section{Introduction:}

Prophylactics of osteoporosis is a very important problem of contemporary therapeutic medicine all over the word [5, 7]. Progredient increasing of population and its ageing, urbanization and global industrialization of modern lifestyle elevates the frequency of new cases of osteoporosis bringing it on the leading position among non-infectious diseases on one level with cardiovascular pathology and cancer [4]. Deficit of essential elements, such as calcium, may be the consequence of a large group of diseases, physiological conditions and functional disturbances. Secondary osteoporosis that has a direct cause is of special value. One of the mechanisms of osteoporosis formation is metabolic acidosis associated with chronic diseases, which results in a negative calcium balance (resorption from bone), which in combination with phosphate depletion induce a metabolic bone disease that exhibits features of both osteoporosis and osteomalacia [14]. Secondary form of osteoporosis has its primary cause - calcium-dependent pathological processes which result in the development of calcium-deficit, osteopenia and osteoporosis. According to the investogations of A.L.Vertkin, the mean frequency of osteopenia and osteoporosis in the cohort of therapeutic patients is 37,3 and $26,9 \%$. The higher this percentage appeared to be in patient with chronic pathology of gastrointestinal tract, diabetes mellitus, chronic obstructive pulmonary disease [1, 3]. Because of the prolonged period when the calcium-deficit is clinically silent and the fact that osteoporosis itself is an irreversible pathology $[7,10]$, prophylactic measures are necessary to prevent the disease $[4,5]$.

That is why early prophylactics of calcium-deficit conditions is very important for primary prophylactics of secondary osteoporosis. It is well known that neither therapeutic nor preventive system in planned without calciumcontaining medications or other sources of calcium. There is a wide spectrum of calcium containing medicinal forms which differ by their effectiveness that depends on the bioavailability of the element. 
Moreover medications have numerous side effects and contraindications. Natural sources of calcium, first of all mineral waters, which contain soluble forms of the element with high biological availability, are of special value in this case [10].

An interventional study in healthy, which were on a free diet, revealed that alkaline bicarbonate and calcium-rich mineral waters administration for 4 weeks decreased bone resorption [11]. In another investigation alkaline supplementation might suggested to be act as supportive therapy [12]. All the high-calcium mineral waters had absorbabilities equal to milk calcium or even slightly better. When tested, all produced biodynamic responses indicative of absorption of appreciable quantities of calcium (ie, increased urinary calcium, decreased serum parathyroid hormone, decreased bone resorption biomarkers, and protection of bone mass).

A conclusion was made that high-calcium mineral waters could provide useful quantities of bioavailable calcium [13]. Calcium-rich mineral waters are an alternative to dairy products as their bioavalability is similar or even better. Bicarbonates are also considered to have a positive effect on bone metabolism. It is generally agreed that an adequate calcium intake is necessary for the acquisition of an ideal peak bone mass and for the maintenance of the bone mineral density in adults, in postmenopausal women, and in the elderly.

These arguments allow to consider natural bicarbonate and calcium-rich mineral waters as an important component of prophylactic programs for the prevention of secondary calcium-deficit conditions.

\section{Aim}

The study was designed to evaluate the calcium and magnesium availability from the calcium-containing mineral water in order to determine whether calciumcontaining mineral waters may be used as an additional source of dietary calcium and to evaluate the possibilities of mineral waters intake for compensation of calciumdeficit at patients with chronic gastroenterological diseases.

\section{Materials and methods}

Overall 110 patients with chronic gastroenterological pathology and risk factors of osteoporosis were observed.

Evaluation of bioelements absorbability from a calcium- and bicarbonate-rich mineral water was studied by the dynamics of their content in the hair before and after the 24-day course of mineral water intake at 18 patients. The levels of calcium, magnesium, phosphor and iron were studied in the laboratory of the "Centre of Biotic Medicine" (Moscow) using atomic emission (Optima 2000 DV, Perkin Elmer, USA) and massspectrometry with inductive argon plasma.

The influence of three different calcium-containing mineral waters on the calcium-magnesium metabolism was studied. The average calcium and magnesium concentrations in the tested mineral waters ranged respectively from 50 to $600 \mathrm{mg} / \mathrm{dl}$ and from 10 to $100 \mathrm{mg} / \mathrm{l}$ table $1)$.

92 patients (age 19 - 61 years) with digestive organs pathology and testified osteoporosis risk factors were examined. None of the patients had disorders or was taking medications known to affect calcium metabolism. The subjects were studied during their usual diet (dietary calcium intake of $\approx 800 \mathrm{mg} / \mathrm{d}$ ). The levels of calcium, phosphor and magnesium in the serum were studied before and after course of mineral waters intake using biochemical analyzer Chemistry analyzer BioChem SA (USA).

\section{Results}

Biological availability of mineral elements was evaluated by the dynamics of their content in the patients' hair, which is one of the most objective non-invasive methods of mineral metabolism investigation. The levels of micro- and 
microelements in the hair corresponds to their concentration in the organism and reflects peculiarities of their metabolism whereas their blood concentration changes only transitorily because of complex homeostatic regulatory systems function. Hair is a metabolic active tissue of the organism and is characterized by certain dynamics of growth $(0,2-0,5 \mathrm{~mm}$ daily). The level of bioelements in hair is much more higher than in serum. For example, the concentration of calcium in the hair is about 200 times higher, magnesium - in 30 times higher than in serum. Hair represents an integral biologic and chemically homogenous structure. That is why its analyzing may be used for real elements absorbability evaluation [6].

Results of the patients' hair analyzing before and after course of internal use of calcium- magnesium-, ironand bicarbonate rich mineral water Soyminska revealed, that levels of all of the studied elements increased. Especially important was simultaneous increasing the levels calcium and iron, which is a problem for modern pharmacology [9] (Table

Table 1 The main composition of calcium-containing mineral waters

\begin{tabular}{|c|c|c|c|c|c|c|c|c|}
\hline \multirow[t]{2}{*}{ Mineral water } & $\mathrm{M}$ & $\mathrm{CO}_{2}$ & $\mathrm{HCO}_{3}$ & $\mathrm{Na}+\mathrm{K}$ & $\mathrm{Ca}$ & $\mathrm{Fe}$ & $\mathrm{Mg}$ & $\mathrm{H}_{2} \mathrm{SiO}_{3}$ \\
\hline & \multicolumn{2}{|c|}{$\mathrm{g} / 1$} & \multicolumn{6}{|c|}{$\mathrm{mg} / \mathrm{l}$} \\
\hline Soyminska & 7,51 & 1,9 & 3308,0 & 1611,7 & 564,0 & 7,3 & 91,7 & 28,5 \\
\hline Shayanska & 2,48 & 1,7 & 1,549 & 554,0 & 98,0 & 4,1 & 11,0 & 70,0 \\
\hline Uzhgorodska & 0,98 & 1,1 & 396,5 & 158,7 & 48,0 & 12,6 & 21,4 & 162,5 \\
\hline \multicolumn{9}{|c|}{ Composition of mineral waters described by Kurlov's formula ${ }^{*}$} \\
\hline \multicolumn{9}{|l|}{ Soyminska } \\
\hline \multicolumn{9}{|c|}{$\mathrm{Cl} 48-54 \mathrm{HCO}_{3} 46-52$} \\
\hline \multicolumn{9}{|l|}{ Shayanska-242 } \\
\hline \multicolumn{9}{|c|}{ 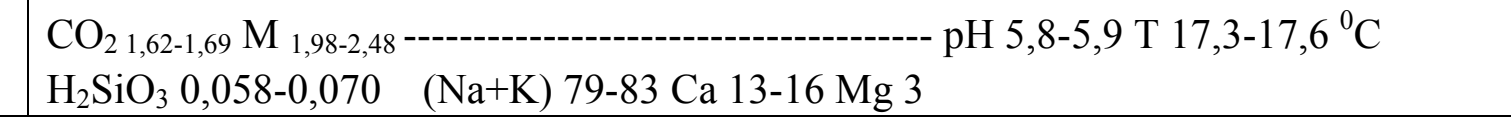 } \\
\hline \multicolumn{9}{|l|}{ Uzhgorodska } \\
\hline \multicolumn{9}{|c|}{$\begin{array}{l}\quad \mathrm{CO}_{20,84-1,09 \mathrm{M}_{0,77}} \\
\mathrm{Fe}^{++} 0,011-0,013 \\
\mathrm{H}_{2} \mathrm{SiO}_{3} 0,90-0,163\end{array}$} \\
\hline
\end{tabular}

Notes: *In balneology Kurlov's formula describes the information about mineral waters. It is a pseudo-fraction, in which in the nominator we indicate anions, in the denominator - cations, which are present in the mineral water in concentrations not less than $5 \%$ equivalents (counting of $100 \%$ per cations and anions). Also we indicate other characteristic chemical components in $\mathrm{g} / \mathrm{l}$, gases and total mineralization in $\mathrm{g} / \mathrm{l}$. After the formula the values of $\mathrm{pH}$ and temperature $(\mathrm{T})$ of the given water are presented. This formula simplifies the classification of mineral waters and allows reflecting their main characteristic physical-chemical peculiarities. 
Table 2 Dynamics of bioelements' concentration in the patients hair under the influence of the course of calcium- and iron-rich mineral water intake

\begin{tabular}{|l|c|c|c|c|}
\hline \multirow{2}{*}{ Biolements } & \multicolumn{2}{|c|}{ Concentration, $\mu \mathrm{g} / \mathrm{g}$} & \multirow{2}{\text{Dynamics}}{$\begin{array}{c}\text { Statistical } \\
\text { (degree of } \\
\text { changes) }\end{array}$} & $\begin{array}{c}\text { accuracy, } \\
\mathrm{P}\end{array}$ \\
\cline { 2 - 3 } Iron & $31,3 \pm 5,4$ & $45,8 \pm 4,3$ & $+1,46$ & $<0,05$ \\
\hline Calcium & $1753,0 \pm 183$ & $2606,7 \pm 317$ & $+1,49$ & $<0,05$ \\
\hline Magnesium & $151,5 \pm 19,7$ & $175,3 \pm 17,0$ & $+1,16$ & $<0,1$ \\
\hline Phosphor & $143,9 \pm 4,8$ & $161,6 \pm 7,0$ & $+1,12$ & $<0,1$ \\
\hline
\end{tabular}

A certain difference exists also in the dynamics of the tested elements concentrations depending on their baseline levels - more distinct dynamics of calcium and magnesium was achieved at patients with lower concentration of these elements before treatment.
No distinct difference in the dynamics of calcium, magnesium and phosphor levels in the serum and their urinary excretion under the influence of different types of mineral waters were found with a tendency of 3-5\% elevation of calcium concentration (Table 3 ).

Table 3 Dynamics of $\mathrm{Ca}, \mathrm{Mg}, \mathrm{P}$ in the serum under the influence of mineral waters with different concentrations of calcium and magnesium

\begin{tabular}{|c|c|c|c|c|}
\hline \multirow[t]{2}{*}{ Elements } & \multicolumn{3}{|c|}{ Mineral waters } & \multirow{2}{*}{$\begin{array}{c}\text { Referent } \\
\text { normal levels }\end{array}$} \\
\hline & Soyminska & Shajanska & Uzhgorodska & \\
\hline \multirow[t]{2}{*}{ Calcium } & $\underline{2,16+0,09}$ & $\underline{2,39+0,04}$ & $2,43+0,06$ & \multirow{5}{*}{$\begin{array}{c}2,5-2,75 \\
\mathrm{mmol} / 1\end{array}$} \\
\hline & $\overline{2,35+0,05}$ & $\overline{2,36+0,06}$ & $\overline{2,32+0,04}$ & \\
\hline $\mathrm{P}$ & $>0,05$ & $>0,05$ & $>0,05$ & \\
\hline \multirow[t]{2}{*}{ Deviations } & $0,75-2,8$ & $1,85-2,90$ & $2,07-2,70$ & \\
\hline & $2,0-3,18$ & $\overline{1,90-3,02}$ & $2,32-2,35$ & \\
\hline \multirow[t]{2}{*}{ Magnesium } & $0,79+0,04$ & $\underline{0,82+0,02}$ & $0,83+0,02$ & \multirow{5}{*}{$\begin{array}{c}0,7-1,2 \\
\mathrm{mmol} / \mathrm{l}\end{array}$} \\
\hline & $\overline{0,80+0,04}$ & $\overline{0,83+0,03}$ & $0,83+0,03$ & \\
\hline $\mathrm{P}$ & $>0,05$ & $>0,05$ & $>0,05$ & \\
\hline \multirow[t]{2}{*}{ Deviations } & $0,51-1,3$ & $0,62-1,17$ & $0,64-1,07$ & \\
\hline & $\overline{0,61-1,11}$ & $\overline{0,49-1,09}$ & $\overline{0,62-0,88}$ & \\
\hline \multirow[t]{2}{*}{ Phosphor } & $\underline{1,05+0,05}$ & $\underline{1,01+0,04}$ & $\underline{0,95+0,04}$ & \multirow{5}{*}{$\begin{array}{c}0,81-1,55 \\
\mathrm{mmol} / 1\end{array}$} \\
\hline & $\overline{1,00+0,04}$ & $\overline{1,08+0,05}$ & $\overline{0,99+0,04}$ & \\
\hline $\mathrm{P}$ & $>0,05$ & $>0,05$ & $>0,05$ & \\
\hline \multirow[t]{2}{*}{ Deviations } & $\underline{0,67-1,73}$ & $\underline{0,71-1,36}$ & $\underline{0,46-1,22}$ & \\
\hline & $0,72-1,41$ & $0,54-1,52$ & $0,65-1,1$ & \\
\hline
\end{tabular}

Notes. Indices in the nominator - before, in the denominator - after the course of treatment, $\mathrm{P}$ - statistical accuracy of differences between these values.

It was found that low gastric acidity, decreased exocrine function of pancreas, hypotonic dyskinesia of gallbladder and cholestasis of different origin, disturbances in the function of urinary system are associated with the decreasing the bioelements absorbability from the meals and their serum concentrations are close to the lower norm. Accounting these peculiarities the regime of mineral waters was developed. 
All of used mineral waters demonstrated positive influence on the calcium-magnesium metabolism, elevating the concentration of these elements in serum and increasing the occurrence of physiologic (normal) levels of bioelements by the end of treatment (Table 4).

Table 4 Normal levels of calcium, magnesium, phosphor in serum under the influence of drinking treatment (in \% before and after treatment, $\mathrm{M} \pm \mathrm{m}$ )

\begin{tabular}{|c|c|c|c|c|}
\hline \multirow{2}{*}{ Bioelements } & \multirow{2}{*}{$\begin{array}{c}\text { Referent } \\
\text { normal levels }\end{array}$} & \multicolumn{3}{|c|}{ Mineral waters } \\
\hline & & Soyminska & Shajanska & Uzhgorodska \\
\hline \multirow[t]{2}{*}{ Calcium } & $2,2-2,75$ & $\underline{36,0 \pm 9,6}$ & $\underline{57,5 \pm 7,8}$ & $\underline{59,0 \pm 9,5}$ \\
\hline & $\mathrm{mmol} / 1$ & $\overline{68,0 \pm 9,3}$ & $\overline{72,5 \pm 7,1}$ & $\overline{81,5 \pm 7,5}$ \\
\hline \multicolumn{2}{|c|}{ Dynamics (degree of changes) } & $+1,89$ & $+1,26$ & $+1,38$ \\
\hline \multicolumn{2}{|l|}{$\mathrm{P}$} & $<0,05$ & $<0,01$ & $<0,01$ \\
\hline \multirow[t]{2}{*}{ Magnesium } & $0,7-1,2$ & $36,0 \pm 9,6$ & $57,5 \pm 7,8$ & $63,0 \pm 9,3$ \\
\hline & $\mathrm{mmol} / \mathrm{l}$ & $\overline{44,0 \pm 9,9}$ & $\overline{65,0 \pm 7,5}$ & $\overline{92,6 \pm 5,0}$ \\
\hline \multicolumn{2}{|c|}{ Dynamics (degree of changes) } & $+1,22$ & $+1,13$ & $+1,45$ \\
\hline \multicolumn{2}{|c|}{  } & $<0,1$ & $<0,05$ & $<0,01$ \\
\hline \multirow[t]{2}{*}{ Phosphor } & $0,81-1,55$ & $92,0 \pm 5,4$ & $\underline{87,5 \pm 5,2}$ & $77,8 \pm 8,0$ \\
\hline & $\mathrm{mmol} / \mathrm{l}$ & $\overline{84,0 \pm 7,3}$ & $\overline{92,5 \pm 4,2}$ & $\overline{74,1 \pm 8,4}$ \\
\hline \multirow{2}{*}{\multicolumn{2}{|c|}{$\begin{array}{l}\text { Dynamics (degree of changes) } \\
\mathrm{P}\end{array}$}} & $-1,10$ & $+1,06$ & $-1,05$ \\
\hline & & $>0,05$ & $>0,05$ & $>0,05$ \\
\hline
\end{tabular}

Notes. Indices in the nominator - before, in the denominator - after the course of treatment, $\mathrm{P}$ - statistical accuracy of differences between these values.

The revealed effect quantitatively depended on the concentrations of bioelements in the serum at the beginning of treatment - the lower was the initial level of calcium the higher was the degree of its elevation and the occurrence of low concentrations of the element by the end of treatment. This regularity was more pronounced for calcium-rich mineral water of Soymi deposit, which has the higher content of calcium. The analogous inverse correlation existed for magnesium. The concentrations of phosphor were normal and didn't change significantly after the treatment. The revealed effect depended also on the content of calcium and magnesium in the given mineral water (Table 5).

Table 5 The correlation coefficient value between calcium and magnesium concentrations in the serum and degree of their elevation under the influence of the course of mineral waters intake

\begin{tabular}{|c|c|c|c|}
\hline \multirow{2}{*}{ Bioelements } & \multicolumn{3}{|c|}{ Mineral waters } \\
\cline { 2 - 4 } & Soyminska & Shajanska & Uzhgorodska \\
\hline Calcium & $-0,83$ & $-0,43$ & $-0,51$ \\
\hline $\mathrm{P}$ & $<0,001$ & $<0,05$ & $<0,05$ \\
\hline Magnesium & $-0,73$ & $-0,39$ & $-0,26$ \\
\hline $\mathrm{P}$ & $<0,001$ & $<0,05$ & $<0,2$ \\
\hline
\end{tabular}

Notes: P - Достовірність коефіцієнта кореляції. $\mathrm{P}$ - statistical accuracy of correlation. 
The obtained result of our investigation testify the positive influence of internal use of natural calciumcontaining mineral waters on the calciummagnesium metabolism. The revealed regularities might be accounted in the methods of differential balneological correction of disturbances in calcium metabolism and primary prophylactics of secondary calcium-deficit conditions.

\section{Conclusions.}

1.Investigation of bioavailability of calcium, magnesium and iron by the dynamics of their content in the hair testified high level of absorption of these elements from the natural mineral water as a result of its intake.

2.Positive changes in the calciummagnesium metabolism may be achieved by internal use of mineral waters with different content of calcium. This fact testifies the dose-depending effect of bioelements pharmacological activity [8]. It is known that even in cases of absence of clinical manifestations of calcium-deficit it is necessary to consume additional amounts of calcium in a minimal daily dose of $50 \mathrm{mg}$. For this preventing purpose natural mineral waters with low concentrations of calcium may be used as an additional everyday source supplement of calcium. Mineral waters with higher content of calcium may be used in the programs of primary prophylaxis of osteoporosis in cases when clinical symptoms of calcium-deficit or high risk of osteoporosis.

3.The positive effect of natural calcium and bicarbonate containing mineral waters on the calcium-magnesium metabolism at patients with digestive organs pathology quantitatively depended on the concentration of calcium and magnesium in the serum at the beginning of treatment and on their content in the mineral water.

4. The results of the present study showed that bicarbonate and calcium containing mineral waters represent an additional dietary source of calcium, which can provide over one-third of the recommended dietary intake of this mineral in adults. Bicarbonates are also considered to have a positive effect on bone metabolism.

5.The revealed regularities serve as a basis for the differential use of natural mineral waters with biologically significant levels of calcium in the programs of primary prophylaxis of osteoporosis and compensation of calciumdeficit conditions. Variety of natural mineral waters with different content of calcium and anionic - cationic composition [1] allow to combine different waters and methods of treatment according to individual peculiarities of the dominating gastroenterological disfunction and degree of calcium-deficit.

\section{References}

1.Головач И.Ю. Нарушения минеральной плотности костной ткани и вторичный остеопороз при патологии гепатобилиарной системы и желудочнокишечного тракта: на перекрестке проблем // Журнал «Боль. Суставы. Позвоночник». - 2012. - N 3 (07);

2.Мікроелементний склад мінеральних вод та медико-географічне зонування Закарпаття / I.C.Лемко, Б.М.Фекийшгазі, Л.П.Киртич [та ін.] // Медична гідрологія та реабілітація. 2005. - Т.3. - № 2. - C.4-13.

3.Остеопороз в практике семейного врача: что мы умеем ? / А.Л.Верткин, А.В.Наумов, Л.Ю.Моргунов [та ін.] // Справочник практического врача. - 2006. - Том 04. № $3 . \quad$ - $\quad$ http://old.consiliummedicum.com/media/refer/06 03/13.shtml

4.Поворознюк В.В. Остеопороз “мовчазна епідемія" / В.В.Поворознюк, Н.В.Григорьева, Т.Ф.Татарчук // Здоров'я України. - 2007. - №3. - С.61;

5.Симоненко В.Б. Остеопороз: современные подходы и новые возможности в профилактике и лечении / В.Б.Симоненко, Е.Е.Волков, 
Н.А.Берестовая // Клиническая медицина. - 2006. - № 9. - С.4-7.

6.Скальная М.Г. О пределах физиологического (нормального) содержания $\mathrm{Ca}, \mathrm{Mg}, \mathrm{P}, \mathrm{Fe}$ и $\mathrm{Cu}$ в волосах человека / М.Г.Скальная, В.А.Демидов, А.В.Скальный // Микроэлементы в медицине. - 2003. - № 4 (2). - С.5-10.

7.Сміян C.I. Сучасні погляди на проблеми лікування i профілактики остеопорозу / С.І.Сміян // Мистецтво лікування. - 2006. - № 9. - С.37-40;

8.Чекман И.С. Кальция цитрат клинико-фармакологическая активность / И.С.Чекман // Провизор. - №11. - 2003: http://www.provisor.com.ua/archive/ 2003/N11/art 24.htm

9.Ших К.В. Взаимодействие железа и кальция / К.В.Ших // РМЖ: «Человек и лекарство». - 2006. - Том 14. - № 4 (256). - С.274-277

10.Use of calcium or calcium in combination with vitamin D supplementation to prevent fractures and bone loss in people aged 50 years and older: a meta-analysis / B.M.Tang, G.D.Eslick, C.Nowson [et al.] // Lancet. 2007. - V.370. - P.657-667.

11.Burckhardt $P$. The effect of bicarbonate on bone metabolism: interventional studies // Contributions of the Second International Acid-Base Symposium. - Munich, Germany, 2006; 12.Cseuz R., Barna I., Bender T., Vormann J. Alkaline mineral supplementation decreased pain in theumatoid arthritis: a randomized, controlled study // Contributions of the Second International Acid-Base Symposium. - Munich, Germany, 2006;

13.Heaney R. Absorbability and utility of calcium in mineral waters // Am. J. Clin. Nutr. - 2006. - Vol. 84. - P.371374

14.Wiederkehr M., Krapf R. Metabolic and endocrine effects of metabolic acidosis in humans // Swiss med WKLY. - 2001. - Vol. 131. - P.127-132. 